\title{
Translocation and spread of piscivorous fishes in the Burdekin River, north-eastern Australia
}

\author{
Brad Pusey $^{1, *}$, Damien Burrows ${ }^{2}$, Angela Arthington ${ }^{1} \&$ Mark Kennard $^{1}$ \\ ${ }^{1}$ CRC for Tropical Rainforest Ecology and Management and Centre for Riverine Landscapes, Griffith \\ University, Nathan, Queensland, 4111, Australia; ${ }^{2}$ Australian Centre for Tropical Freshwater Research, \\ James Cook University, Townsville, Queensland, 4811, Australia; *Author for correspondence (e-mail: \\ bpusey@westnet.com.au; fax: +6-18-97568612)
}

Received 8 December 2004; accepted in revised form 11 July 2005

Key words: flow regime, foodweb structure, Lates, Macquaria, Oxyeleotris, translocation

\begin{abstract}
The distribution of the biogeographically distinctive fish fauna of the Burdekin River, north-eastern Australia, is largely determined by the presence of a large waterfall located at the lower quarter of the river's length. Downstream of the falls, assemblages are characterised by the presence of piscivorous fishes whereas such species are largely absent from upstream reaches. Sleepy cod (Oxyeleotris lineolatus), a large piscivorous gudgeon, was first introduced into the upper reaches of the Burdekin River in 1980 and other releases, both official and unofficial, have occurred subsequently. The population remained small and restricted to the site of introduction for a decade, but expanded in size and distribution after the occurrence of a large flood and entry into a prolonged period of drought. This gudgeon is now present in every tributary system of the Burdekin Basin. Despite the occurrence of substantial temporal variation in fish abundance due to a highly variable flow regime, negative impacts on one species, a small gudgeon (Mogurnda adspersa), are evident. Both deliberate and accidental releases of other species into the upper Burdekin River have also occurred, often to satisfy recreational fishing demand. Such species are typified by large size and piscivorous habit, characteristics alien and inimical to the native fish fauna. It is hypothesised that these piscivorous species may have even greater impact than $O$. lineolatus in some tributary systems of the upper Burdekin River.
\end{abstract}

\section{Introduction}

Intentional release into northern Australian fresh waters of alien fishes suitable for recreational fishing has been strenuously opposed (e.g., Barlow and Lisle 1987) because of the many associated negative environmental and ecological effects (Courtenay and Stauffer 1984; Moyle 1986; Moyle et al. 1986; Welcomme 1988; Arthington 1991; Crowl et al. 1992). However, this concern has not been equally expressed with regard to the translocation of native fishes outside their natural range.
Arthington (1991) and Burrows (2004) cautioned that there was no reason to believe that the consequences associated with the introduction of non-native indigenous species would be any different to those arising from the introduction of fishes from other countries. Intense pressure for the introduction of sport fishes into Queensland fresh waters, particularly impoundments, resulted in the establishment of the Recreational Fishing Enhancement Program by the Queensland Department of Primary Industries in 1986 - a program designed to facilitate the translocation 
of native fishes to establish or enhance recreational fisheries throughout the State. Nearly 30 million fish from over 20 species have been stocked in Queensland waterways since 1986 and the rate of stocking is increasing (Burrows 2004). Nearly 1.5 million fish have been officially stocked in various locations throughout the Burdekin River, northern Queensland (Table 1, Figure 1). There has been no assessment of the environmental and ecological consequences of fish stocking in the region and until recently, no planning to protect areas of conservation significance.

Meaningful assessment of the impact of a translocation or introduction event may be hampered by a lack of information about the ecological status of the receiving system prior to the event. Moreover, when such information does exist, it may not be in a form amenable to rigorous quantitative treatment because: (a) information is drawn from several different sources; (b) the design of such studies was never intended to accommodate other unforeseen investigations; or (c) because sampling methods vary between studies. Similarly, a failure to monitor the effects of an introduction event after it has occurred, other than to determine whether it has been successful (in the case of deliberate introduction), makes assessment of any negative consequence difficult. This may be especially the case in regions remote from population centres and for which resources are scarce or when introductions are carried out under the auspices of local community-based stocking groups that may lack the financial resources to undertake follow-up research, be under

Table 1. The number of barramundi (Lates calcarifer) and sleepy cod (Oxyeleotris lineolatus) officially stocked into various locations in the Burdekin River basin and associated tributaries.

\begin{tabular}{lrc}
\hline Waterbody & Barramundi & Sleepy cod \\
\hline Valley of Lagoons & & 8,500 \\
Charters Towers Weir & 32,000 & \\
Lake Dalrymple & 511,400 & \\
(Burdekin Falls Dam) & & \\
Eungella Dam & 238,000 & 47,760 \\
Collinsville Weir & 80,000 & \\
Bowen River & 15,560 & \\
Clare Weir & 445,844 & \\
\hline
\end{tabular}

Information sourced from the QFISH stocking database. no obligation to do so, or have little interest in the negative consequences of their activities. Finally, in the case where prior information exists, it is frequently in the form of difficult-toaccess 'grey' literature (i.e., government agency reports). The present paper discusses the sequence of invasion and impacts on fish biodiversity and ecological processes of three translocated species: a large gudgeon Oxyeleotris lineolatus (Steindachner); barramundi Lates calcarifer (Bloch); and yellowbelly or golden perch Macquaria ambigua (Richardson), in the Burdekin River basin. The information presented here was collected as a part of research in the river basin not specifically aimed at investigating the impact of non-native species. As a consequence, this report must unavoidably take the form of a narrative account of the translocation history, spread and impact (real and potential) of these species.

\section{Study area and ecological background}

The Burdekin River (Figure 1) is a large $\left(130,000 \mathrm{~km}^{2}\right)$, low gradient river with a highly variable flow regime (Pusey and Arthington 1996; Puckridge et al. 1998) (Figure 2). Two extreme events have occurred in the last 15 years: the 1991 flood was the second largest on record and was followed by a four-year drought containing the 2nd and 3rd lowest annual discharges on record. The upper reaches of the river in the vicinity of Valley of Lagoons (Figure 1) are typified by a series of deep waterholes connected by meandering reaches of moderate flow and occasionally by short stretches of rocky rapids. For many hundreds of kilometres downstream of this area, the river is characterised by low-gradient reaches with low to moderate flow over a sand substrate. Habitat diversity is uniformly low, water quality is good and periods of 'cease-to-flow' are normally limited (Pusey and Arthington 1996; Pusey et al. 1998). Tributary systems are not greatly dissimilar in habitat structure or wetseason water quality to the upper Burdekin River, although reaches of faster flow and coarse substrate occur more frequently in the upper reaches of these tributaries. Small waterfalls (2$5 \mathrm{~m}$ ) occur in some tributaries. Cease-to-flow conditions are more common in tributaries and 


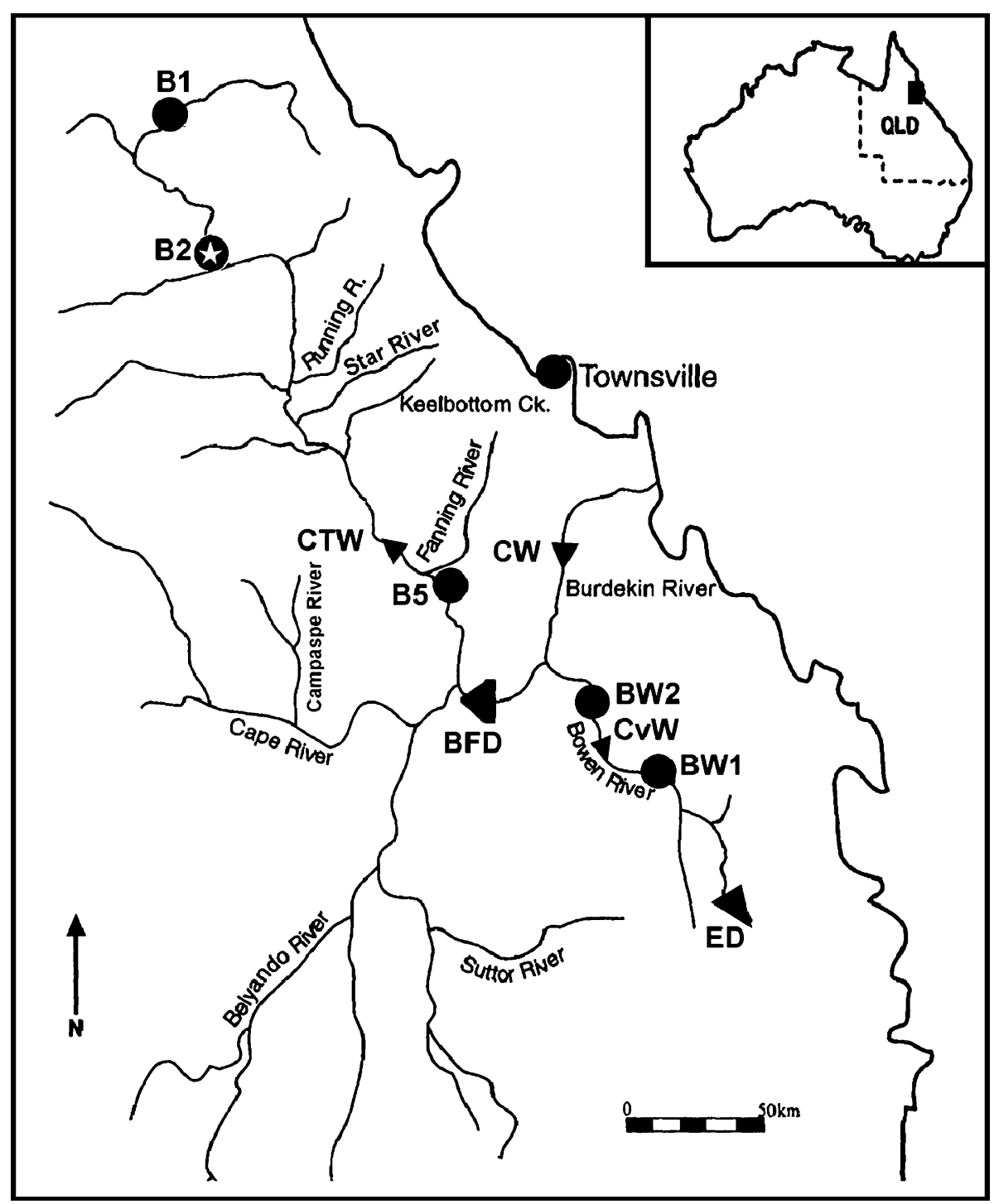

Figure 1. Map of the Burdekin River and major tributary systems. Weirs and dams are designated by $\boldsymbol{\Lambda}$. Localities mentioned in the text are given. The location of the gauging station upon which Figure 2 is based is designated by $\mathrm{B} 1$ - Valley of Lagoons; B2 - Blue Range Station; B5 - Macrossans Crossing; BW1 - Bowen River 1; BW2 - Bowen River 2; CTW - Charters Tower Weir; BFD - Burdekin Falls Dam (Lake Dalrymple); CW - Clare Weir; CvW - Collinsville Weir; and ED - Eungella Dam.

are typically limited to the dry season during which time habitat availability is limited and water quality may deteriorate (Pusey et al. 1998; Burrows and Tait 1999). The Belyando/Suttor Rivers and the Cape/Campaspe Rivers are very low gradient tributary systems of the upper Burdekin River typified by greatly elevated turbidity (up to $500 \mathrm{NTU}$ ) and extended periods of cease-to-flow conditions (Pusey and Arthington 1996; Pusey et al. 1998; Burrows et al. 1999;
Burrows 2001). The Bowen River, a major tributary of the lower Burdekin River, is characterised by consistently good water quality, perennial flows, higher gradient and habitats with elevated water velocity and coarse substrates (Pusey and Arthington 1996; Pusey et al. 1998).

Several impoundments occur along the river's length: the largest of which are Lake Dalrymple (Burdekin Falls Dam (BFD) - 1,860,000 megalitres $(\mathrm{ML}))$ on the Burdekin River and Eungella 


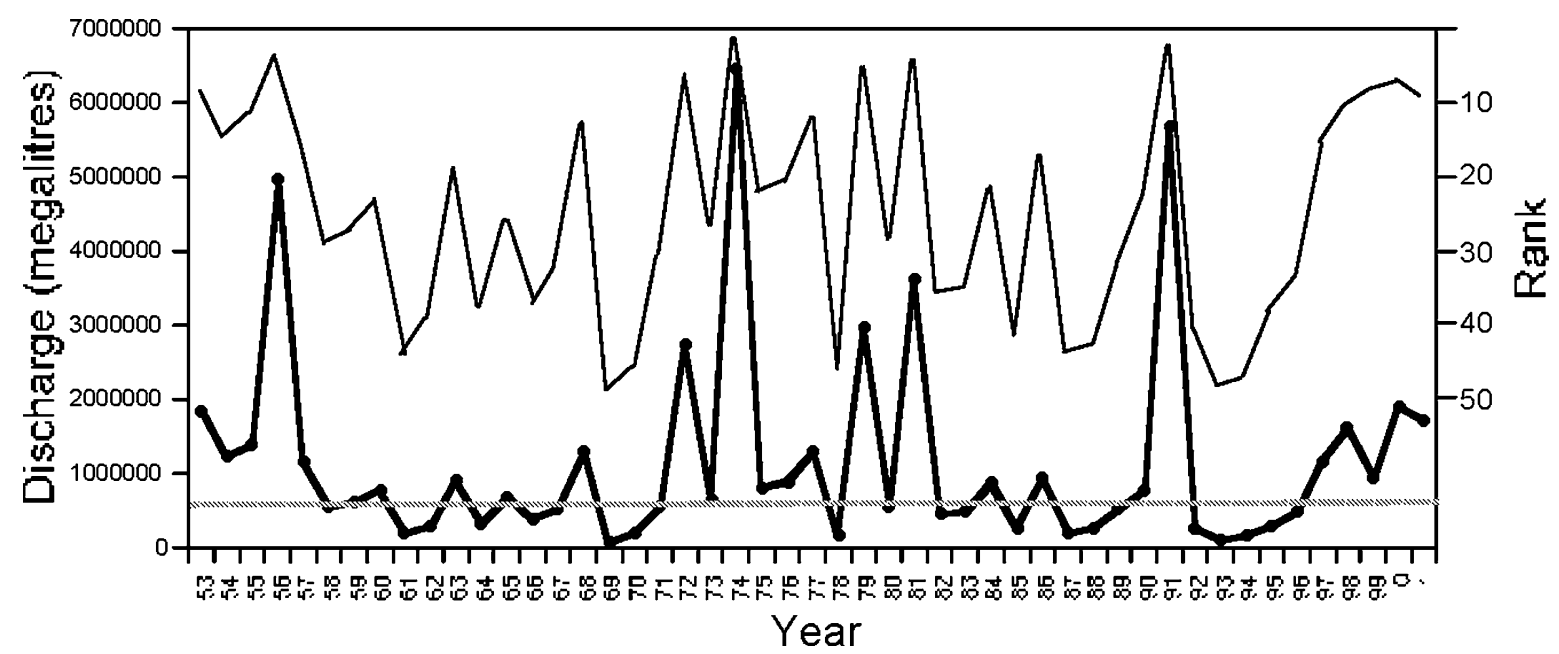

Figure 2. Annual discharge (in megalitres) at Blue Range Station (120107B) in the upper Burdekin River over the period 1952/53 to $2000 / 2001$. The thick line represents annual discharge and the thin line represents the ranking from 1 (highest) to 49 (lowest) for each year over the entire period of record. Median flow is depicted by the broken line.

Dam (131,000 ML) on the Broken River, a major tributary of the Bowen River (Figure 1). Several smaller impoundments, including Charters Towers Weir, Clare Weir and Collinsville Weir, are also present (Figure 1). The Burdekin Falls Dam was constructed in 1984 at the head of a large waterfall. The Burdekin Falls and the subsequent dam are important in determining the distribution of fishes in the river. Diadromous, estuarine vagrant, or lowland river species, such as river whaler (Carcharhinus leucas), sawfish (Pristis spp.), barramundi (Lates calcarifer) and long tom (Strongylura kreffti) occur in the lower Burdekin River and significantly, such species are piscivorous (Allen et al. 2002; Pusey et al. 2004). With the exception of a small number of eels (Anguilla reinhardtii), such lowland species are denied access to the upper reaches of the river (Pusey et al. 1998). Upstream of the Burdekin Falls, at least two endemic species (Scortum parviceps, a terapontid grunter, and Neosilurus mollespiculum, a plotosid catfish) are abundant and widely distributed. Piscivorous fishes are mostly naturally absent.

\section{Data sources}

With the exception of Pusey et al. (1998), the studies upon which this report is based consist of unpublished reports to government or unpublished data sets. Midgley (1977) surveyed eight sites located throughout the basin using a variety of passive and active sampling methods (i.e., nets and baited line). Sites were sampled once in 1976. Electrofishing, either boat or back-pack, was not employed in that study but was the dominant sampling method used in the studies discussed below. Of these, all but Hogan and Vallance (2000) used single-pass back-pack electrofishing over a distance between 100 and $200 \mathrm{~m}$ of stream length and fish abundances were standardised to a CPUE of $100 \mathrm{~min}$ total electrofishing time. Pusey et al. (1998) surveyed 12 sites broadly distributed throughout the catchment, including the tributary systems Fletcher Creek, Keelbottom Creek, Fanning River and Running River upstream of the BFD and the Bowen River downstream of the BFD. Each site was sampled four times over the period 1990-1992. Burrows and Tait (1999) sampled nine sites spread evenly between Running River, Keelbottom Creek and Fanning River. These sites were sampled on one occasion only in 1999. Burrows et al. (1999) surveyed five sites in the Belyando River on one occasion in 1999 and 14 sites spread widely throughout the Cape Campaspe River system on one occasion only in 2000 (Burrows 2001). Pusey and Arthington (unpublished data) sampled five of the 12 sites originally 
surveyed by Pusey et al. (1998). These sites were sampled annually over the period 1993-1997 and their location is depicted in Figure 1. Hogan and Vallance (2000) surveyed 10 sites throughout the catchment by boat electrofishing.

\section{The translocation and spread of sleepy cod (Oxyeleotris lineolatus)}

Oxyeleotris lineolatus is not native to the Burdekin River basin (Pusey et al. 2004). Anecdotal accounts of its presence in the lower Burdekin River (J. Tait, pers. comm.) and the Bowen/Broken River (cited in Midgley 1977) date to the 1970s and there are no confirmed records of its presence prior to this period. Officially sanctioned introductions of $O$. lineolatus commenced in 1980-1983 with the release of 8,500 hatcheryreared fish into the upper reaches of the Burdekin River (Valley of Lagoons - site B1 in Figures 1 and 3). Eungella Dam on the Broken/ Bowen River was stocked with fingerlings as follows: 1,950 (1980), 35,000 (1986), 5,810 (1990) and 5,000 (1998) (Queensland Fisheries Service Freshwater Fish Stocking Data Base - QFISH). The presence of $O$. lineolatus in the lower Bowen River and lower Burdekin River over the period 1989-1992 (Pusey et al. 1998) suggests either prior undocumented introductions or that stocked fish escaped from Eungella Dam on one of the few occasions it overflowed.

Oxyeleotris lineolatus was uncommon over the period 1989-1992 when electrofishing catches in the upper Burdekin River never exceeded two individuals per occasion (Pusey et al. 1998). Catches were dominated by large mature fish (Figure 4) and restricted to the site of introduction (Site B1 - Figures 1 and 3). This situation continued until 1994 when 18 individuals were recorded at Blue Range Station (Site B2, approximately $150 \mathrm{~km}$ downstream of B1) and six individuals were collected from the river at Macrossan's Crossing near Charters Towers (site B5), a further $150 \mathrm{~km}$ downstream from B2 (Figures 3 and 5). By 1995, the O. lineolatus catch at Blue Range Station increased (39 individuals collected) but no similar increase in abundance was recorded at Macrossan's Crossing (Figure 5). Electrofishing catches remained

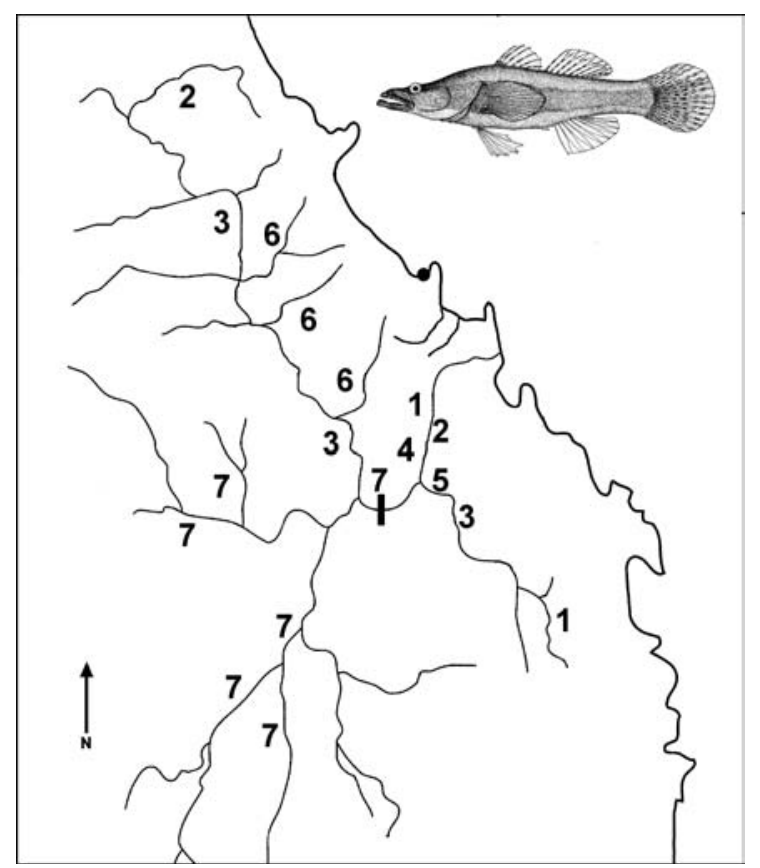

Figure 3. Expansion of the distribution of Oxyeleotris lineolatus in the Burdekin River catchment. 1, pre 1980; 2, 1980-1992; 3, 1994; 4, 1995; 5, 1997; 6, 1999; and 7, 2000. Refer to Figure 1 for tributary and location names.

high and relatively stable at Blue Range Station in 1996 and 1997 but an increase from 5 to 70 individuals per sample was detected at Macrossan's Crossing (Figure 5). The sequential increase in population size over time down the length of the river is suggestive of a 'colonising front' moving downstream. Changes in population size structure at individual sites suggest that this colonising front was composed mostly of small juvenile and sub-adult fishes (Figure 4). We suggest that after progression of the colonising front, the remaining fish matured, reproduced and provided additional recruits available to colonise further downstream. We acknowledge that estimates of population size derived from single pass electrofishing may be variable and in north-eastern Australia this is primarily a problem when estimating abundance for open water school species (Kennard et al. unpublished data). Oxyeleotris lineolatus is more typically associated with root masses and undercut banks (Pusey et al. 2004) and it is highly unlikely that the temporal differences in abundance reported here are due to sampling error and anything other than real 


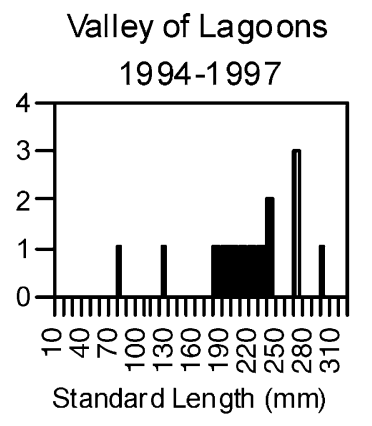

Blue Range Station

1994

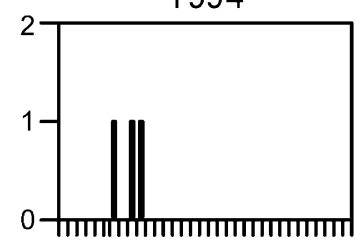

1995

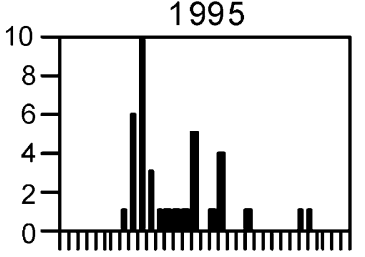

1996

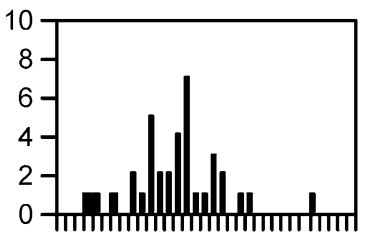

1997

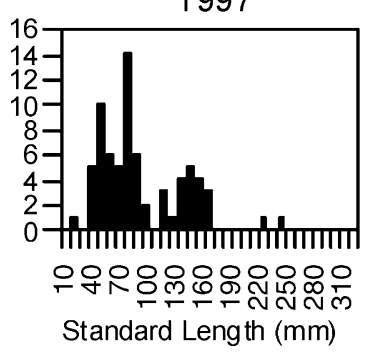

Macrossan's Crossing

Bowen River

$1994-1997$

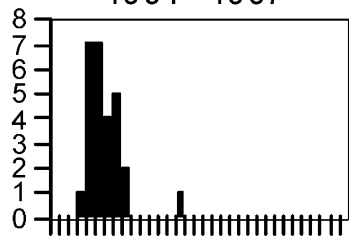

$1994 \& 1995$

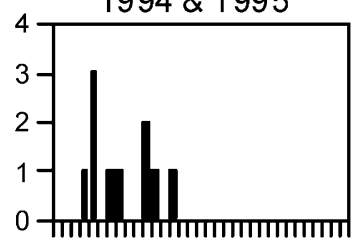

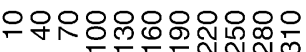

Standard Length (mm)

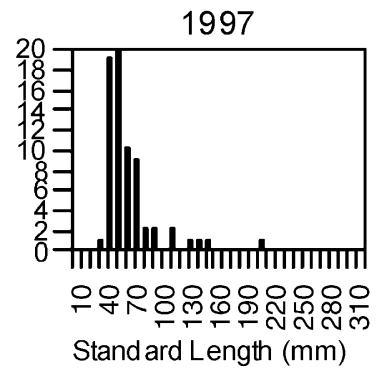

Figure 4. Population size structure of Oxyeleotris lineolatus at three locations in the upper Burdekin River and pooled across two locations in the Bowen River over the period 1994-1997. Data are pooled within locations and years if total sample size was small. No data were available for Macrossan's Crossing in 1996. Fish $<100,100-200$ and $>200 \mathrm{~mm}$ SL are designated juvenile, subadult and adult, respectively.

increases in abundance over time. Note also that prior to expansion of the $O$. lineolatus population (i.e., pre 1993), electrofishing catches were always two individuals or less per sample; greatly less than recorded in the expansion phase (post 1993).

Oxyeleotris lineolatus was absent from tributary systems of the upper Burdekin over the period 1990-1992, but was widely distributed in Keelbottom Creek and the Star and Fanning Rivers by 1999 (Burrows and Tait 1999). Local landholders report that $O$. lineolatus was first observed in Keelbottom Creek in 1998 (pers. comm. to D. Burrows). The only reaches found not to contain $O$. lineolatus were those situated above natural barriers to movement (i.e., waterfalls on Fanning River and Keelbottom Creek) or those located far upstream (i.e., Star River) (Burrows and Tait 1999). Oxyeleotris lineolatus was detected in Lake Dalrymple (Hogan and Vallance 2000) and at several sites in the Belyando River (Burrows et al. 1999) in 1999, and from the Cape/Campaspe River in 2000 (Burrows 2001) (Figure 3). Although documented translocation of $O$. lineolatus into the upper Burdekin River is limited to the event at Valley 


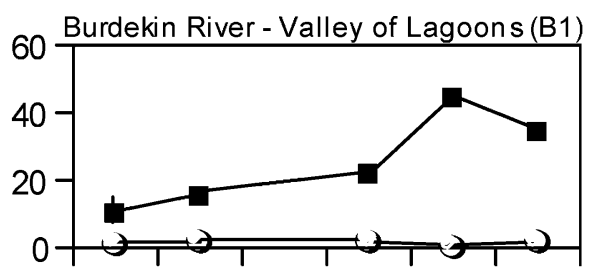

Burdekin River - Blue Range Station (B2)
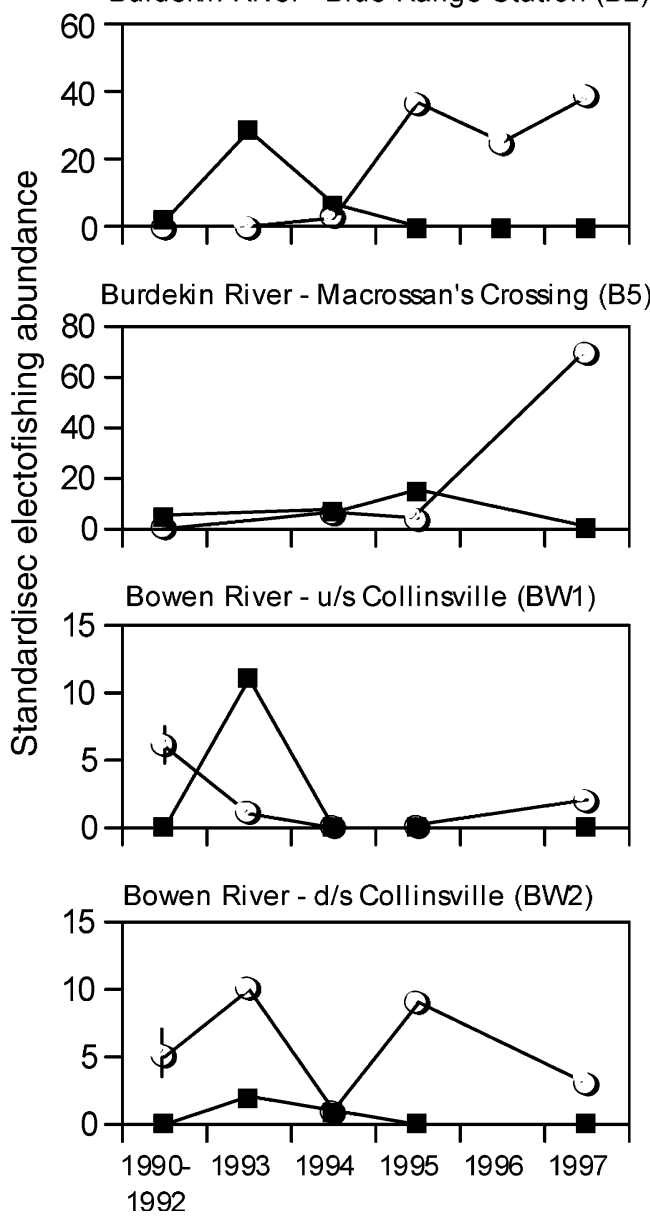

Figure 5. Changes in abundance of Oxyeleotris lineolatus (o) and $M$. adspersa ( $(\mathbf{)})$ at different sites in the Burdekin River catchment over the period 1990-1997. Abundances shown represent the number of fishes collected in $100 \mathrm{~min}$ of electrofishing on each occasion. Value shown for the period 19901992 is the mean of five separate abundance estimates made over that period. Error bar=1 SD. Error bar smaller than the width of the symbol in some cases.

of Lagoons, it is possible that the spread of this species in the south-western sub-catchments has been facilitated by other events also. For example, farm dams and both main channel and off- channel waterbodies in the Belyando, Suttor and Cape River drainages were apparently stocked with non-native fishes such as $O$. lineolatus and Macquaria ambigua during the 1980s and 1990s (pers. comm. to D. Burrows).

It is reasonable to assume that $O$. lineolatus has now invaded every available tributary system of the upper Burdekin River, and that this has occurred in less than a decade (i.e., post-egress from the point of introduction). Marchetti et al. (2004) characterised the invasion of new systems by alien species as being composed of four distinct phases: transport, establishment, spread and integration; and identified propagule pressure, parental care, a long life span and a well-developed physiological tolerance to water quality extremes as being positively associated with success during the establishment phase. Similar traits were identified as correlates of invasion success in Mediterranean streams (Vila-Gispert et al. 2005). Oxyeleotris $l i$ neolatus occurs throughout northern Australia, is highly fecund (average egg mass size $=43,130$ eggs), fans and guards a well defined nest until the eggs hatch, may live for 5-7 years and can tolerate a wide range of water $\mathrm{pH}$ (4.8-9.2), temperature $\left(18-38{ }^{\circ} \mathrm{C}\right)$, dissolved oxygen (1.0$10.2 \mathrm{ppm})$ and water clarity (0.1-579 NTU) (Pusey et al. 2004). Arthington (1991) and Gido et al. (2004) also noted that successful invading species are typically tolerant of a wide range of environmental conditions.

The establishment phase for $O$. lineolatus in the Burdekin River lasted approximately 10 years during which time it was restricted to the point of introduction. 'Sleeper' or 'dormant species;' introduced species for which the expansion phase is preceded by a long period of apparent dormancy, have been described previously (Bruton 1986). The spread phase of such species is believed to be facilitated by some form of environmental stress that inhibits the ability of natural communities to resist invasion (Arthington et al. 1990; Moyle and Light 1996). Several reviews (e.g., Moyle 1986; Arthington et al. 1990; Kennard et al. 2005) have found that although fish species have been introduced into a wide variety of environments, the greatest success has been achieved in habitats disturbed by human activities and in particular, those subjected to flow regime change. In the case of $O$. lineolatus, 
expansion appears related to the concatenation of two natural, albeit extreme, events (record high flow followed by record drought) between 1991 and 1996. This set of flow conditions led first to a major increase in the abundance of native species (due to enhanced recruitment associated with an increase in habitat availability and food abundance following the 1991 flood) followed by a rapid decline in abundance as flows declined and the fish became restricted to ever reducing habitat (Pusey et al. 2004). Marchetti et al. (2004) noted that a long life span (positive influence), distance from the nearest source population (negative), adult trophic status (herbivores less likely to spread) and a history of prior invasion success (positive) were all associated with the spread phase of an invading species. Note, however, that Marchetti et al. (2004) quantified spread as the number of separate catchments in which an invading species occurred, not the rate of spread within a catchment after it has become established. None-the-less, the long life span of $O$. lineolatus and its carnivorous habit may increase its capacity to spread quickly. It is highly likely that a natural tendency for dispersal increases the rate of spread also. Most colonisation in the Burdekin River has been achieved by juvenile and sub-adult, not adult fish (Figure 4). The movement biology of $O$. lineolatus has not been studied in detail and it is not known if such migratory behaviour occurs in their natural habitats (Pusey et al. 2004). However, widespread dispersal by juveniles and sub-adults is a distinctive feature of the freshwater fish fauna of northern Australia (and of eleotrids in particular) and may be advantageous in systems that experience great fluctuations in habitat availability and distribution due to variable flow regime (Pusey et al. 2004). Moreover, dispersal in the juvenile phase may be an imperative when microhabitat use varies little with ontogeny and adults predate upon juveniles.

Elton (1958) coined the term 'ecological resistance' (subsequently divided by Moyle and Light 1996; into three interactive elements: biotic, demographic and environmental) to describe the barriers with which each newly invading species interacts. Biotic resistance is the effect that the recipient community has an influencing invasion success through the presence of parasites, preda- tors, pathogens and competitors. Large gudgeons are absent from the upper Burdekin River and other large-bodied species such as Hephaestus fuliginosus and Scortum parviceps are primarily omnivorous consuming prawns, shrimps, algae and macrophytes; consequently few competitors and no major predators exist in the upper Burdekin River. There appear to be few habitats in the river that have not been invaded by $O$. lineolatus (except those located above barriers to movement) consistent with a wide tolerance to varying water quality conditions and a diverse mesohabitat use (Merrick and Schmida 1984; Pusey et al. 2004). A common characteristic of successful biological invaders is the ability to tolerate a wide range of variability in climate and habitat structure (Swincer 1986). Arriving species with wide tolerance limits and broad habitat requirements are likely to be more versatile and so better able to survive and reproduce in the receiving community (Pimm 1989).

\section{Other translocated fish in the Burdekin River: barramundi (Lates calcarifer) and yellowbelly (Macquaria ambigua)}

Lates calcarifer is stocked extensively in the Burdekin River including locations previously outside its natural distribution (i.e., areas upstream of the Burdekin Falls including Lake Dalrymple, Charters Tower Weir, upper Broken River). Given its current presence in the Charters Towers Weir, barramundi may in the future colonise much of the river upstream of this point and anecdotal evidence cited in Burrows and Tait (1999) suggests this may have already occurred. Similar expansion into the Suttor/Belyando systems can be expected, if stocking continues in Lake Dalrymple. Note that L. calcarifer cannot breed in freshwater, a fact often disingenuously used by proponents of fish translocation to downplay potential negative ecological impacts. Continued stocking of source populations is little different to natural recruitment for a species in which spawning and nursery grounds (i.e., estuaries) are spatially distinct from juvenile and adult habitats (i.e., upstream riverine habitats). Arthington and Bluhdorn (1996) comment that introduced species do not have to reproduce in 
the new environment to have an impact. A sustained predatory or competitive effect on indigenous species may follow the release of long-lived species (Baltz 1991).

Macquaria ambigua, a large percichthyid native to southern Australia, has been deliberately introduced into the Burdekin River on a number of occasions. The first introduction (100 small fish sourced from the Narrandera Research Station, NSW and a further 12 fish from the Thomson River catchment, part of the Lake Eyre basin), occurred at Valley of Lagoons Station in the 1970s (Midgley 1977; A. Atkinson, pers. comm. to D. Burrows). This population apparently failed to establish although it persisted for about 10 years. Limited stocking of the lotic waters upstream of the Clare Weir occurred in the mid-1970s, but appears to have been unsuccessful also (Alex Hamlyn, QDPI; pers. comm.). Undocumented and unofficial introductions of $M$. ambigua into farm dams and local waterways have been common in the last three decades of the 20th century. For example, M. ambigua were stocked into an overflow channel of the Burdekin River downstream of the Macrossan road crossing in 1987 (Burrows, unpubl. data). The second route of introduction was via accidental escape from an aquaculture facility during the extreme floods associated with Cyclone Joy in 1991 and a self-sustaining expanding population has now become established in the river. Populations have been detected recently in the Campaspe River (Burrows 2001) and in the Belyando River (Burrows et al. 1999). Pastoralists in the upper Cape River first reported this species in 1997-1998 (pers. comm. to D. Burrows) and it has been collected in the impounded reaches of the Burdekin Falls Dam (Burrows 2001) and downstream of the dam also (Hogan and Vallance 2000).

Both the Campaspe and Suttor/Belyando rivers are notable for their high turbidity and in this regard, they resemble rivers found across the native range of $M$. ambigua (Merrick and Schmida 1984). It is very likely that this species will fare well in the future with populations expanding in size and range, particularly as these river systems lack an appreciably sized competitor (i.e., Hephaestus fuliginosus). Burrows (1999), in an environmental scoping study for water infrastructure development in the Burdekin River, suggested that new developments could lead to increases in the levels of suspended solids. Any water resource development in the catchment that results in increased water turbidity is likely to favour M. ambigua, to the detriment of native fishes less tolerant to such conditions. In addition, this species is able to spawn in impoundments and has previously been shown to become widespread and abundant in north-eastern Australian rivers after translocation (Pusey et al. 2004).

\section{Impacts associated with $\boldsymbol{O}$. lineolatus in the Burdekin River}

The purple-spotted gudgeon Mogurnda adspersa is a small eleotrid gudgeon $(<70 \mathrm{~mm} \mathrm{SL})$. Recent revision of the genus Mogurnda in Australia (Allen and Jenkins 1999) has resulted in formal recognition of four new species and genetic evidence suggests that the species currently recognised as $M$. adspersa in north-eastern Queensland is composed of a number of additional distinct taxa also (D. Hurwood, pers. comm.). The spread of $O$. lineolatus appears to be concomitant with a decline in abundance of $M$. adspersa in the Burdekin River. This gudgeon was common at Blue Range Station (B2) in 1993 (e.g., 30 fish collected in $100 \mathrm{~min}$ of electrofishing) prior to invasion by $O$. lineolatus but abundance levels had declined to only five and one fish per sample within 1 and 2 years, respectively, of its arrival. It was completely absent from electrofishing catches in 1996 and 1997 (Figure 5). A similar pattern was observed at Macrossan's Crossing. Mogurnda adspersa and $O$. lineolatus co-existed whilst the latter was at low abundance but $M$. adspersa was driven to apparent local extinction by 1997 when $O$. lineolatus abundances were at their greatest. Mogurnda adspersa were either at low abundance or absent from the two Bowen River sites at which populations of $O$. lineolatus have long been established (Figure 5).

Further evidence of an impact by $O$. lineolatus on $M$. adspersa is provided by abundance and distribution data for these two species in tributary streams of the upper Burdekin River (Burrows and Tait 1999; Burrows 2001). Note however, that most samples were collected post- 
invasion and pre-impact abundance data are limited. Mean abundance levels at one site in the Fanning River and one site in Keelbottom Creek, over the period 1990-1992, were available as putative controls (Pusey et al. 1998). Collectively, these data suggest that $M$. adspersa is able to reach high abundances in sites in which $O$. $l i$ neolatus is absent or at low abundance ( 2 or less per sample) (Figure 6). It is noteworthy that the two sites with the highest abundance of $M$. adspersa were both located above waterfalls and not yet accessed by $O$. lineolatus. Under conditions in which sleepy cod achieved moderate to high abundance ( $>5$ fish per sample), $M$. adspersa were either absent or at comparatively low abundance.

Oxyeleotris lineolatus may directly have an impact on $M$. adspersa through competition and predation. Both species have almost identical microhabitat requirements with a high dependency on available cover, particularly the fine

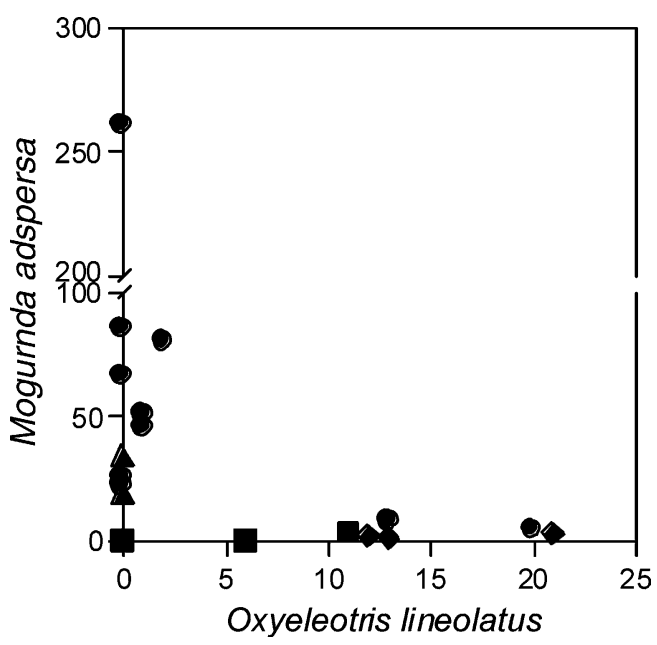

Figure 6. Comparison of the abundance of Oxyeleotris lineolatus and Mogurnda adspersa (number of fish collected in 100 min of electrofishing) in the Fanning River, Keelbottom Creek and Star River of the upper Burdekin River ( $)$ (Burrows \& Tait 1999), the Fanning River and Keelbottom Creek (ム) (Pusey et al. 1998), the Cape and Campaspe rivers $(\diamond)$ (Burrows 2001) and the Belyando River (ロ) (Burrows et al. 1999). The data included from Pusey et al. (1998) are the arithmetic means of abundances determined on four occasions over the period 1990-1992 (the SD were 18 and $29 \%$ of the mean for the Fanning River and Keelbottom Creek, respectively) and represent abundance values prior to invasion of these systems by $O$. lineolatus. root masses of riparian trees; furthermore the diet of juvenile $O$. lineolatus is very similar to that of M. adspersa (Pusey et al. 2004). Sub-adult (100$200 \mathrm{~mm}$ SL) and adult $O$. lineolatus are piscivorous, with more than $50 \%$ of the diet being composed of fish. Even fish of $100 \mathrm{~mm} \mathrm{SL}$ are able to ingest large $M$. adspersa (unpubl. obs.). Elsewhere, the closely related $O$. heterodon is piscivorous $(63 \%$ of total diet) and the fish component comprised of a single prey species, another gudgeon (Coates 1992). If such an extreme reliance on a single species occurs in the interaction between $O$. lineolatus and $M$. adspersa, then rapid declines in population size of the latter species seem inevitable. Even so, it seems unlikely that the spread of $O$. lineolatus throughout the Burdekin River system will lead to the total elimination of $M$. adspersa from the river. For example, O. $l i$ neolatus and $M$. adspersa appear able to coexist in aquatic habitats of the Valley of Lagoons (B1) (Figure 5). Moreover, most studies of the impact of invading species on freshwater systems report few extinctions and a general tendency for species diversity to increase due to the addition of non-native species (e.g., Gido and Brown 1999; Rahel 2002; Gido et al. 2004; Ricciardi and Atkinson 2004). However, Ricciardi and Atkinson (2004) caution that lag times measured in decades may obscure ecological impacts. Extinctions in systems invaded by alien species may frequently be more a response to loss or degradation of key habitats than to alien species per se (Olden and Poff 2004), not withstanding the fact that habitat degradation may favour alien species (Ross et al. 2001; Bunn and Arthington 2002; Kennard et al. 2005).

\section{Changes to food web structure}

Piscivory is common in the lower reaches of tropical Australian rivers (Pusey et al. 2000) whereas the absence of predominantly piscivorous fishes is a feature of the food web in the upper reaches of the Burdekin River and its tributaries (i.e., above the Burdekin Falls). Fish prey make up less than $4 \%$ of the diet of any native species in the unregulated upper Burdekin River (Pusey and Arthington, unpublished data). In contrast, more than $50 \%$ of the adult diet of 
O. lineolatus, L. calcarifer and M. ambigua is comprised of fish (Pusey et al. 2004). Increased extent and strength of piscivory in previously largely predator-free habitats is highly likely to have negative impacts on the native fish fauna. Localised and rapid extinction of predator-naive species following the translocation of piscivorous fishes has been demonstrated in northern Australia (Barlow et al. 1987) and elsewhere (Bruton 1986; Moyle 1986; Crowl et al. 1992). It is notable that acknowledgement of the potential for predation to impact on native fishes was critical in the abandonment of the program to introduce Nile perch (Lates niloticus) into northern Australia (Barlow and Lisle 1987). Yet, ironically, a closely-related, similarly-sized, piscivorous congener is assumed not to be problematic simply because it is native to the region and cannot breed in freshwater (see also Arthington 1991).

\section{Conclusion}

To date, the translocation or introduction of non-native fishes into the Burdekin River has occurred without prior assessment of the likely impacts of such actions, or indeed, subsequent assessment of any impacts that may have arisen. In the case of the $O$. lineolatus, its introduction and subsequent spread throughout the catchment appear to have negatively impacted on at least one native fish species. Predation by adults, and to a lesser extent, competition with juvenile $O$. lineolatus, appear to be the most likely ecological mechanisms responsible for the decline of $M$. adspersa in the Burdekin catchment. Naturally high levels of temporal variation in abundance of most species in the Burdekin River (Pusey et al. 2004) makes detection of impacts associated with the introduction of non-native fishes difficult. However, the absence of large predatory fishes in the upper part of the river means that predation pressure is highly likely to increase in impoundments and unregulated reaches to which translocated predaceous species have access. Negative impacts are highly likely to occur. Future attempts to assess the impacts of other processes occurring in the catchment, particularly impacts of increasing water resource use and the establishment of associated infrastructure (Bunn and
Arthington 2002), will be greatly hampered if the impacts associated with fish introductions are not fully documented and understood. Fish play important roles in the ecology of streams and rivers (Power 1990, 1992); the impact on biodiversity that results from the deliberate and accidental introduction of non-native fishes has substantial consequences for the maintenance of biodiversity and ecosystem processes, and consequently environmental and human health.

\section{Acknowledgements}

We wish to thank the many people who assisted with the field work and laboratory analysis that contributed to this work, particularly Jim Tait and Martin Read. The many landholders that allowed access to the river are also gratefully acknowledged. Discharge data were provided by the Queensland Department of Natural Resources and Mines. The Land and Water Resources Research and Development Corporation and the Rainforest CRC supported Pusey and Arthington during the collection of some of the data upon which this paper is based. Two anonymous reviewers are also thanked for their contribution to the manuscript.

\section{References}

Allen GR and Jenkins AP (1999) A review of the Australian freshwater gudgeons, genus Mogurnda (Eleotridae) with descriptions of three new species aqua. Journal of Ichthyology and Aquatic Biology 3: 141-156

Allen GR, Midgley SH and Allen M (2002) Field Guide to the Freshwater Fishes of Australia. Western Australian Museum, Perth, pp. 394

Arthington AH (1991) Ecological and genetic impacts of introduced and translocated freshwater fishes in Australia. Canadian Journal of Fisheries and Aquatic Sciences 48: 33-43

Arthington AH and Bluhdorn DR (1996) The effects of species interactions resulting from aquaculture operations. In: Baird DJ, Beveridge MC, Kelly LA and Muir JF (eds) Aquaculture and Water Resource Management, pp 114-138. Blackwell Science, Oxford

Arthington AH, Hamlet S and Bluhdorn DR (1990) The role of habitat disturbance in the establishment of introduced warmwater fishes in Australia. In: Pollard DA (ed) Introduced and Translocated Fishes and Their Ecological Effects, pp 61-66. Australian Government Publishing Service, Canberra Bureau of Rural Resources Proceedings No. 8 
Barlow CG and Lisle A (1987) Biology of the Nile Perch Lates niloticus (Pisces: Centropomidae) with reference to its proposed role as a sport fish in Australia. Biological Conservation 39: 269-289

Barlow CG, Hogan AE and Rogers LG (1987) Implications of translocated fishes in the apparent extinctions in the wild of the Lake Eacham rainbowfish, Melanotaenia eachamensis. Australian Journal of Marine and Freshwater Research 38: 897-902

Baltz DM (1991) Introduced fishes in marine systems and inland seas. Biological Conservation 56: 151-177

Bruton MN (1986) Life history styles of invasive fishes in southern Africa. In: McDonald IAW, Kruger FJ and Ferrar AA (eds) The Ecology and Management of Biological Invasions in Southern Africa, pp 201-208. Oxford University Press, Cape Town

Bunn SE and Arthington AH (2002) Basic principles and ecological consequences of altered flow regimes for aquatic biodiversity. Environmental Management 30: 492-507

Burrows DW (1999) An Initial Environmental Assessment of Water Infrastructure Options in the Burdekin Catchment. James Cook University, TownsvilleReport No. 99/29 Australian Centre for Tropical Freshwater Research

Burrows DW (2001) Monitoring Riparian Environments in the Dalrymple Shire with Respect to the Benefits of Fencing Year 2 Report. Report No. 01/03 Australian Centre for Tropical Freshwater Research, James Cook University

Burrows DW (2004) Translocated Fishes in Streams of the Wet Tropics Region, North Queensland: Distribution and Impact. Cooperative Research Centre for Tropical Rainforest Ecology and Management, Cairns pp. 83

Burrows DW and Tait JP (1999) Fish and Crustacean Survey of the Townsville Field Training Area (TFTA). James Cook University, TownsvilleReport No. 99/18 Australian Centre for Tropical Freshwater Research

Burrows D, Faithful J, Kutt A, Tait J and Blunden L (1999) Environmental study of a proposed dam at Mount Douglas on the Belyando River. James Cook University, Townsville pp. 32 Report No 99/20 Australian Centre for Tropical freshwater Research

Coates D (1992) Biology of Oxyeleotris heterodon and its major prey, Ophieleotris aporos, two floodplain sleepers (Pisces: Eleotridae) of the Sepik River fishery, northern Papua New Guinea. Environmental Biology of Fishes 34: 51-64

Courtenay WR and Stauffer JR Jr (1984) Distribution, Ecology and Management of Exotic Fishes. John Hopkins University Press, Baltimore

Crowl TA, Townsend CR and McIntosh AR (1992) The impact of introduced brown and rainbow trout on native fish: the case of Australasia. Reviews in Fish Biology and Fisheries 2: 217-241

Elton CS (1958) The Ecology of Invasions by Animals and Plants. John Wiley, New York, pp. 181

Gido KB and Brown JH (1999) Invasion of North American drainages by alien fish species. Freshwater Biology 42: 387-399

Gido KB, Schaefer JF and Pigg J (2004) Patterns of fish invasions in the Great Plains of North America. Biological Conservation 118: 121-131
Hogan AE and Vallance T (2000) Summary of the Burdekin River Fisheries Reports. Queensland Department of Primary Industries, Walkamin

Kennard MJ, Arthington AH, Pusey BJ and Harch BD (2005) Are alien fish a reliable indicator of river health? Freshwater Biology 50: 174-193

Merrick JR and Schmida GE (1984) Australian Freshwater Fishes: Biology and Management. Griffin Press Ltd., Netley, South Australia

Midgley SH (1977) Burdekin River. Queensland Fisheries Service Special Report No. 10. 18 pp plus appendices

Marchetti MP, Moyle P and Levine R (2004) Invasive species profiling? Exploring the characteristics of non-native fishes across invasion stages in California. Freshwater Biology 49: 646-661

Moyle PB (1986) Fish introductions into North America: patterns and ecological impact. In: Mooney HA and Drake JA (eds) Ecology of Biological Invasions of North America and Hawaii, pp 27-43. Springer-Verlag

Moyle PB, Daniels RA, Herbold JC and Baltz DM (1986) Annual and long-term patterns in distribution and abundance of a noncoevolved assemblage of estuarine fishes in California. Fishery Bulletin 84: 105-117

Moyle PB and Light T (1996) Fish invasions in California: do abiotic factors determine success? Ecology 77: 1666-1670

Olden JD and Poff NL (2004) Ecological processes driving biotic homogenisation: testing a mechanistic model using fish faunas. Ecology 85: 1867-1875

Pimm SL (1989) Theories of predicting success and impact of introduced species. In: Drake JA, Mooney HA, Castri FD, Groves RH, Kruger FJ, Rejmanek $M$ and Williamson $M$ (eds) Biological Invasions, A Global Perspective, SCOPE 37 , pp 351-367. John Wiley \& Sons, Chichester

Power ME (1990) Effects of fish in river food webs. Science 250: 411-415

Power ME (1992) Habitat heterogeneity and the functional significance of fish in river food webs. Ecology 73: 1675-1688

Puckridge JT, Sheldon F, Walker KF and Boulton AJ (1998) Flow variability and the ecology of arid zone rivers. Marine and Freshwater Research 49: 55-72

Pusey BJ and Arthington AH (1996) Stream flow variability within the Burdekin River Basin, Queensland: implications for in-stream flow management. In: Water and the Environment. Proceedings of the 23rd Hydrology and Water Resources Symposium, pp 213-220. Australian Institute of Engineers, Barton

Pusey BJ, Arthington AH and Read MG (1998) Freshwater fishes of the Burdekin River, Australia: biogeography, history and spatial variation in community structure. Environmental Biology of Fishes 53: 303-318

Pusey BJ, Arthington AH and Read MG (2000) The dry-season diet of freshwater fishes in monsoonal tropical rivers of Cape York Peninsula, Australia. Ecology of Freshwater Fish 9: 177-190

Pusey BJ, Kennard MJ and Arthington AH (2004) Freshwater Fishes of North-Eastern Australia. CSIRO Publishing, Melbourne, pp. 684

Rahel FJ (2002) Homogenization of freshwater faunas. American Review of Ecology and Systematics 33: 291-315 
Ricciardi A and Atkinson SK (2004) Distinctiveness magnifies the impact of biological invaders in aquatic systems. Ecology Letters 7: 781-784

Ross RM, Lellis WA, Bennett RM and Johnson CS (2001) Landscape determinants of nonindigenous fish invasions. Biological Invasions 3: 347-361

Swincer DE (1986) Physical characteristics of sites in relation to invasions. In: Groves RH and Burdon JJ (eds) Ecology of
Biological Invasions: An Australian Perspective, pp 67-76. Australian Academy of Science, Canberra

Vila-Gispert A, Alcarez C and Garcia-Berthou E (2005) Life history traits in small Mediterranean streams. Biological Invasions 7: 107-116

Welcomme RL (1988) International introductions of inland aquatic species. Food and Agriculture Organisation of the United Nations, Rome, 318 FAO Fisheries Technical Paper pp. 294 